\title{
Cyanobacterial blooms in natural waters in southern Portugal: a water management perspective
}

\author{
Helena M. Galvão ${ }^{1, *}$, Margarida P. Reis ${ }^{1}$, Elisabete Valério ${ }^{2}$, Rita B. Domingues ${ }^{1}$, \\ Cristina Costa ${ }^{1}$, Dulce Lourenço ${ }^{3}$, Sílvia Condinho ${ }^{3}$, Rute Miguel ${ }^{1}$, Ana Barbosa ${ }^{1}$, \\ Conceição Gago ${ }^{4}$, Natália Faria ${ }^{2}$, Sérgio Paulino ${ }^{2}$, Paulo Pereira ${ }^{2}$
}

${ }^{1}$ Faculdade de Ciências do Mar e do Ambiente (FCMA), Universidade do Algarve, Campus de Gambelas, 8005-139 Faro, Portugal ${ }^{2}$ National Health Institute Dr. Ricardo Jorge, Av. Padre Cruz, 1649-016 Lisboa, Portugal

${ }^{3}$ Águas do Algarve, S.A., Rua do Repouso $n^{\circ}$ 10, 8000-302 Faro, Portugal

${ }^{4}$ CCDR Algarve (Ambiente e Ordenamento), R. Dr. José de Matos n 13, 8000-503 Faro, Portugal

\begin{abstract}
This synthesis of 3 studies from 2 regions of southern Portugal (Alentejo and Algarve) was part of a workshop focusing on cyanobacteria held at the SAME 10. The first study monitored impacts of the large Alqueva dam on the Guadiana estuary since 1996, revealing changes in sediment load, nutrient regime and phytoplankton succession. Prior to dam construction, dense cyanobacterial blooms occurred in the upper estuary during summer and fall. After dam construction, chlorophyll concentration, phytoplankton diversity and abundances of cyanobacteria decreased, contrary to predictions. Mycrocystins remained at low levels in the seston and undetectable in water samples, except during summer 2003 when the particulate fraction contained $1 \mathrm{\mu g} \mathrm{l}^{-1}$, while chlorophyll concentrations and abundances of potentially toxic cyanobacteria remained low. Algarve reservoirs studied since 2001 revealed differences in phytoplankton dynamics. In the western mesotrophic reservoirs (Bravura and Funcho), 40 to $50 \%$ of surface samples contained cyanobacterial concentrations of $\geq 2000$ cells $\mathrm{ml}^{-1}$, while over $80 \%$ of samples from the eastern oligotrophic reservoirs (Odeleite and Beliche) exceeded this value. Spring blooms were dominated by Oscillatoriales in Odeleite and Beliche and by Chroococcales in Bravura and Funcho. Bloom composition seemed to depend on water temperature and management strategies, while toxin concentrations reflected the increased biomass of toxic species. Finally, phytoplankton communities and microcystin production in 5 Alentejo freshwater reservoirs were studied from May to December 2005 and April to July 2006. Cyanobacterial blooms occurred, with varying intensities, not only during summer but also occasionally in winter. Microcystins were detected in $23 \%$ of the samples $(\mathrm{n}=51)$, but without correlation with cyanobacterial biomass. Although Microcystis aeruginosa seemed to be the major producer of microcystins, other potentially toxic species were found. In summary, the varying pattern of cyanobacterial bloom occurrence and toxicity requires a systematic approach to monitoring programs for adequate risk assessment.
\end{abstract}

KEY WORDS: Cyanobacteria $\cdot$ Microcystins $\cdot$ Phytoplankton $\cdot$ Estuary $\cdot$ Freshwater reservoirs

\section{INTRODUCTION}

Shifts in the relative abundance of microalgae within phytoplankton communities define seasonal successions of organisms belonging to different taxa. Phytoplankton successions in natural waters of temperate regions have been well documented for decades
(Hutchinson 1967, Smetacek 1985, Cloern 1996). While a great variety of eukaryotic microalgae and cyanobacteria usually coexist in the same water body in late spring and early summer, this diversity may drop drastically towards the end of summer, giving way to the mass development of cyanobacterial populations (Hutchinson 1961, Rocha et al. 2002). 
Alhough this pattern of seasonal succession can be assumed to be a general trend, phytoplankton dynamics are affected by a more complex scenario of internal and external driving factors, in which different species interact not only with each other but also with the environment, rendering any attempt at prediction or modeling particularly challenging. In the last few decades, a lot of effort has been invested in discerning which environmental factors control bloom formation, especially with respect to toxic species such as cyanobacteria. Understanding the conditions that trigger toxic blooms of cyanobacteria in lakes, reservoirs and rivers is a complex quest, hindered by the lack of information on natural ecological relationships between plankton populations.

Blooms of cyanobacteria have been repeatedly associated with eutrophication processes (Berg et al. 1987, Carmichael et al. 1988, Druvietis 1997, Pinckney et al. 1998, Codd 2000, Chorus 2005). Factors such as high water retention time in lakes and reservoirs, increased temperature, low N:P ratio, as well as surface radiation and wind conditions have been reported to influence bloom development (Carmichael 1996, Kononen et al. 1996, Kawara et al. 1998, Chorus \& Bartram 1999). Most species preferentially occur in stable, well stratified water bodies that provide optimal conditions for their vertical migration. Species like Microcystis aeruginosa and Anabaena spp. contain intracellular gas vesicles and become buoyant, accumulating on the water surface where they can be blown around by the wind, forming very dense stable scums that are easily detected by simple observation of the water reservoir from above (Dittmann \& Wiegand 2006). In contrast, other species like Planktothrix spp. and Oscillatoria spp. are more sensitive to high light conditions and usually tend to accumulate in deeper water layers or disperse homogeneously in the water column (Dittmann \& Wiegand 2006).

Cyanobacterial blooms can be harmful to humans due to the ability of several bloom-forming species to synthesize highly toxic secondary metabolites: cyanotoxins (Dittmann \& Wiegand 2006). Hepatotoxic microcystins are the most commonly found and widespread cyanotoxins. They are associated with several bloomforming genera of cyanobacteria, including Microcystis, Anabaena, Anabaenopsis, Planktothrix, Nostoc, Hapalosiphon, Snowella, Woronichinia, and Oscillatoria (Codd et al. 2005, Falconer 2005). However, not all cyanobacteria are capable of toxin production. Different strains may produce different types of toxins in different quantities and at different rates along their growth cycle, while others are non-toxigenic (Sivonen \& Jones 1999, Codd et al. 2005). These characteristics explain why the occurrence of toxic blooms in natural environments is, apparently, unpredictable.
Current awareness of hazards from toxic cyanobacteria in different countries has made considerable progress due to cooperative programs between countries and regions that are aimed towards implementing existing regulations (Chorus 2005). The prevention of harmful cyanobacterial blooms has been based on the assessment and minimization of eutrophication conditions, thus falling within the scope of the EU Water Framework Directive, which calls for a 'good ecological status' of public water resources by 2015 .

A general picture of the extent of cyanobacterial and cyanotoxin occurrence is emerging from scientific research, preliminary surveys and on-going monitoring in many countries (Chorus 2005). In Portugal, awareness of potential health risks has led to several research projects on freshwater and estuarine microbial ecology in the southern regions of Alentejo and Algarve. Furthermore, a working group, coordinated by the Portuguese General Directorate for Health, was formed in 1995-1996 to present a proposal for a national monitoring program of cyanobacteria and cyanotoxins in freshwater reservoirs. Since then, various laboratories have been carrying out regular screening of cyanobacteria in many freshwater reservoirs, alerting environmental and water management agencies to the more serious toxic occurrences and assessing the efficiency of water treatment processes in removing cyanobacteria and associated toxins.

The southwest region of the Iberian Peninsula is a semi-arid region with a Mediterranean climate where the dry season usually extends from May to September and annual precipitation averages ca. $500 \mathrm{~mm}$. The concentration of rainy days defines a torrential regime, where years of extended droughts alternate with years of intense rain and floods. Water reservoir management is strongly limited by water availability, leading to several situations of high hydraulic residence time while new dam construction further restricts river flow. All these conditions influence the development of cyanobacterial blooms and aggravate their environmental and economic impact.

This paper presents 3 different case studies from Alentejo and Algarve. The studies were presented at a workshop on harmful algal blooms, focusing primarily on cyanobacteria, organized within the SAME 10 held in September 2007 in Faro, Portugal. The first study focuses on the Guadiana River estuary, which runs through both regions. The second study compares cyanobacterial dynamics in 4 freshwater reservoirs of the Algarve region (Bravura, Funcho, Odeleite and Beliche), and the third relates microcystin production with the community composition of cyanobacteria in 5 reservoirs from the Alentejo region (Alqueva, Alvito, Enxoé, Odivelas and Roxo). Although describing different situations in terms of cyanobacterial occurrence 


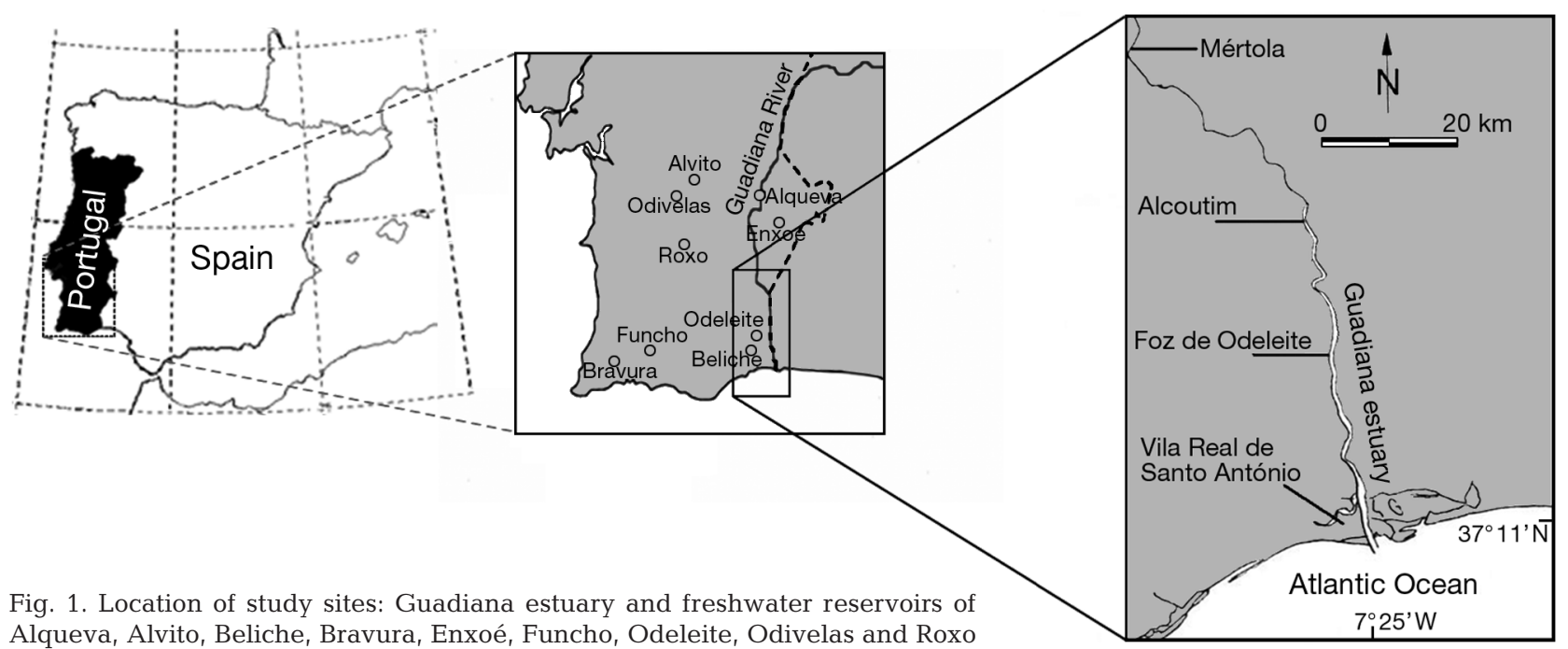

and toxicity, these 3 case studies represent complementary approaches to understanding the complexity of cyanobacterial blooms in Portuguese environments.

\section{IMPACT OF DAM CONSTRUCTION ON THE GUADIANA ESTUARY}

The Guadiana River, running along the southern border between Portugal and Spain (Fig. 1), has the fourth largest drainage basin of all Iberian rivers $\left(67840 \mathrm{~km}^{2}\right)$, but a series of dams have severely restricted its freshwater flow by ca. $75 \%$, and the construction of the large Alqueva dam increased flow regulation to up to $81 \%$ of the total catchment area $\left(55000 \mathrm{~km}^{2}\right)$ starting in 2003.

Cyanobacterial blooms have been reported in the Guadiana River in association with seasons and/or years of low freshwater flow (Cabeçadas \& Brogueira 1981, Oliveira 1985, 1991). Microbial ecology studies carried out from 1996 to 1998 showed a well-defined chlorophyll maximum in the upper estuary (Fig. 2), ca. $30 \mathrm{~km}$ upstream from the mouth of the river (Rocha et al. 2002, Domingues et al. 2005). This observation has been made in many temperate estuaries where estuarine circulation leads to the development of a maximum turbidity zone at the toe of the salt-wedge, upstream of which phytoplankton find optimal conditions for growth (Cloern 1987, 1996, 1999). Moreover, Rocha et al. (2002) indicated that high winter loads of nitrogen and phosphorus in the upper estuary were followed by silicate depletion during early spring caused by spring diatom blooms. This nutrient regime determined the phytoplankton succession from diatoms in early spring to chlorophytes, followed by cyanobacteria during summer and fall (Rocha et al. 2002, Domingues et al. 2005).
Changes in freshwater flow lead to alterations in water quality and hydrography, thus affecting phytoplankton composition and succession. River flow after completion of the Alqueva dam was severely restricted even during winter months with high rainfall (Fig. 3). During the period of dam construction (1999 to 2000), the sediment load transported downstream increased dramatically, causing severe photolimitation for the phytoplankton and resulting in the absence of blooms and very low chlorophyll values throughout spring and summer. One exception occurred in April 2001, when chlorophyll reached a record high of $216 \mu \mathrm{g} \mathrm{l}^{-1}$ due to an unknown chain-forming centric diatom coinciding with a sharp decrease in seston when dam construction was terminated (Fig. 4). Afterwards, during the filling period of the reservoir (2002 to 2003), nutrient concentrations as well as cyanobacterial abundance increased, while diatom abundance remained low (Domingues et al. 2007). After this period, total phytoplankton abundance and succes-

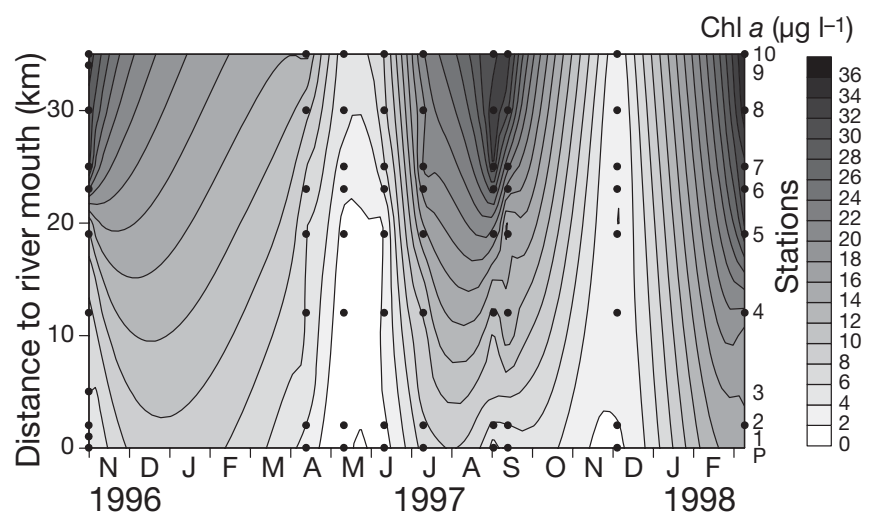

Fig. 2. Interpolation plots showing the longitudinal and seasonal distribution of surface chl a concentrations at selected stations in the Guadiana estuary (P: river mouth, 1: Vila Real St. Antonio, 6: Odeleite Stream, 10: Alcoutim) 


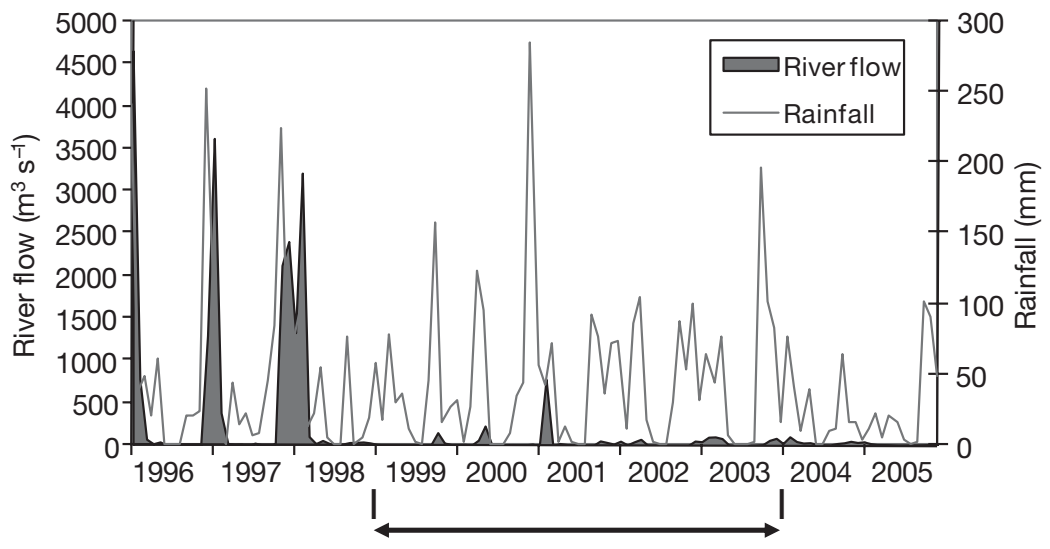

Fig. 3. Monthly river flow volume (Pulo do Lobo upstream from Mértola, mean values) and total monthly rainfall (Alcoutim) from 1996 to 2005 in the upper Guadiana estuary (data source: www.inag.pt/SNIRH/). The arrow marks the dam construction and filling period

sion followed the typical trend observed before dam filling. However, specific diversity and chlorophyll concentrations decreased from 2002 to 2005 (Domingues \& Galvão 2007).

Microcosm studies undertaken in 2005 to explain the phytoplankton community structure based on nutrient regime indicated that nitrogen limitation could have influenced phytoplankton succession (R. B. Domingues unpubl. data). However, this type of experiment was not designed to simulate an important factor, namely estuarine circulation. In fact, the salinity regime in the estuary was affected during dam filling and construction due to the salt-wedge intrusion reaching further upstream, causing saltwater to be detected in the normally freshwater upper estuary (ca. $70 \mathrm{~km}$ upstream from the river mouth). The phytoplankton community found in the upper estuary, including cyanobacteria, was composed strictly of freshwater species with limited halotolerance. Therefore, an increase in salinity, particularly during late spring and early summer when maximum growth should occur, could have had a deleterious impact resulting in lower chlorophyll values and species numbers after construction of the Alqueva dam.

Microcystins were detected in 1999, 2000, 2002 (Caetano et al. 2001, Sobrino et al. 2004), 2004 and 2005 (H. M. Galvão unpubl. data) in concentrations well below the World Health Organization (WHO) guideline for drinking water of $1 \mu \mathrm{g}^{-1}$ (WHO 1998). Microcystin levels remained low, even during cyanobacterial blooms with abundances of potentially toxic species, such as Microcystis aeruginosa, reaching $10^{6}$ to $10^{8}$ cells $\mathrm{ml}^{-1}$
(Caetano et al. 2001, Rocha et al. 2002). Microcystin concentrations higher than the WHO guideline were detected only once, on 25 July 2003, when values of $1.2 \mu \mathrm{g} \mathrm{l}^{-1}$ were reached in Mértola $(70 \mathrm{~km}$ upstream from the river mouth) and $6.8 \mu \mathrm{g} \mathrm{l}^{-1}$ upstream from Mértola (C. Sobrino unpubl. data). Interestingly, these higher toxin levels were detected while total cyanobacteria counts, determined using epifluorescence microscopy (Haas 1982), were relatively low (maximum of $6 \times 10^{5}$ cells $\mathrm{ml}^{-1}$ ) and potentially toxic genera such as $M$. aeruginosa registered low abundance. However, these low total counts could have reflected a shift in predominance from chroococcoid species towards filamentous forms such as Oscillatoria and Anabaena spp. with higher specific biomass and potential toxin production. Furthermore, other samples taken on 30 July 2003 (M. R. Reis unpubl. data) contained high numbers of $M$. aeruginosa $\left(>6 \times 10^{5}\right.$ cell $\left.\mathrm{ml}^{-1}\right)$ and potentially toxic filamentous forms $\left(>1 \times 10^{5}\right.$ cells $\left.\mathrm{ml}^{-1}\right)$. Bathing and fishing in this area were forbidden by health authorities during July and August 2003 because high toxin concentrations persisted for several weeks.

\section{Cyanobacterial blooms in freshwater reservoirs in the Algarve region}

In the Algarve, strong demographic changes induced by tourism have led to the building of several freshwater reservoirs in order to ensure the water quantities required for activities such as agriculture, golf, landscaping and human consumption. Thus, from 2000 onwards, there was a shift from groundwater to surface water as a source of drinking water.

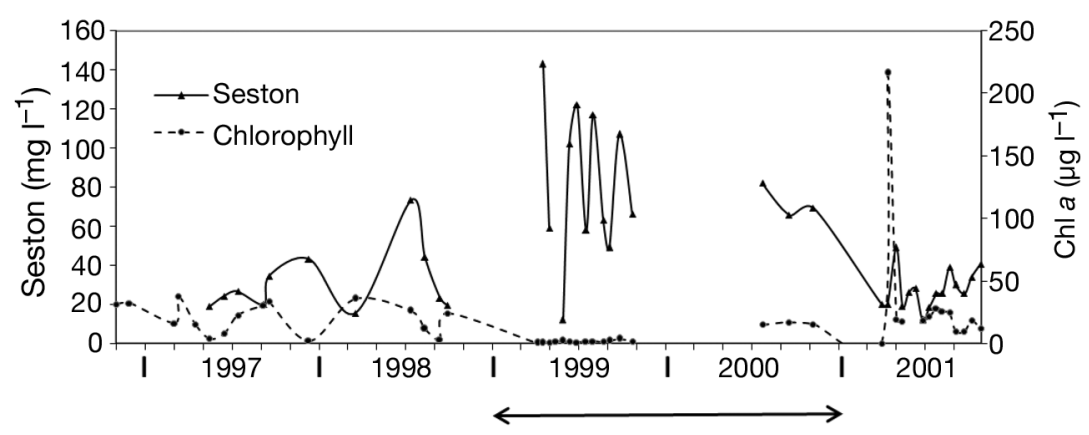

Fig. 4. Seston and chl a concentrations in surface water samples from 1997 to 2001 at the Alcoutim station in the upper Guadiana estuary. The arrow marks the dam construction period. Gaps in the data reflect periods without regular sampling 
In western Algarve, the main reservoir used for drinking water production is Funcho (Fig. 1), while water removal from Bravura is seasonal, usually occurring from May to October. The eastern Algarve is supplied by water from Beliche, which is connected to the Odeleite reservoir by underwater sluices that regulate the flow from Odeleite to Beliche and which are usually opened in spring and closed in autumn. Basic information about location and dimension of the 4 main reservoirs in the Algarve is compiled in Table 1.

These reservoirs have been subject to standard physical, chemical and microbiological water quality monitoring since 1996 and, since 2001, to simultaneous monitoring of phytoplankton and cyanobacteria toxins. We organized all collected data into 2 types of database: one containing a long-term data series of physical and chemical variables and one with a shorter data series, but including biological data and diversity indices like Shannon diversity, eveness, Berger-Parker dominance (Berger \& Parker 1970) and species richness (Magurran 1988). For the present study, multivariate analysis of these data sets was carried out in order to assess the main factors triggering cyanobacteria blooms.

Relative abundances of cyanobacteria and microcystin concentrations obtained over a $2.5 \mathrm{yr}$ period in the western and eastern Algarve are illustrated in Figs. $5 \& 6$, respectively. In the western reservoirs, 40 to $50 \%$ of the water samples contained cyanobacterial concentrations higher than the WHO alert level 1 for raw waters $\left(\geq 2000\right.$ cells $\left.\mathrm{ml}^{-1}\right)$. However, more than $80 \%$ of the samples in Odeleite and Beliche exceeded this alert level. Furthermore, 13 to $17 \%$ of all analyzed samples presented concentrations of $>20000$ cells $\mathrm{ml}^{-1}$, but WHO alert level $2\left(\geq 100000\right.$ cells $\left.\mathrm{ml}^{-1}\right)$ was only occasionally exceeded in Funcho in 2001, 2002 and 2005, when Microcystis spp. reached $>10^{6}$ cells $\mathrm{ml}^{-1}$. Microcystin concentrations were always negligible with respect to human health risk, only exceeding WHO guideline value of $1 \mu \mathrm{g}^{-1}$ in scums of a winter bloom detected in Funcho in 2002, and in bottom samples of a spring bloom detected in Beliche in 2004.

Cyanobacterial blooms occurred during the dry as well as during the rainy season, and no evident relationship between weather conditions and bloom occurrence was found. Data analyses of monthly water column profiles for temperature and oxygen concentrations revealed strong differences in the stratification of the 4 reservoirs (M. R. Reis unpubl. data), probably related to the different water management strategies. While Funcho reservoir behaved as a warm monomictic lake with winter destratification occurring only from December to February, the Bravura water column tended to destratify 2 mo earlier and stratify 2 to 3 mo

\begin{tabular}{|c|c|c|}
\hline 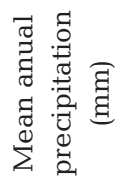 & 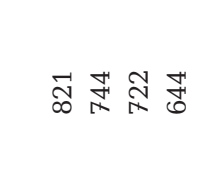 & 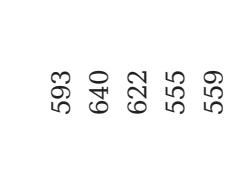 \\
\hline 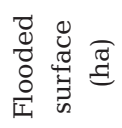 & 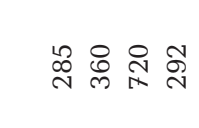 & 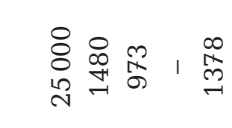 \\
\hline 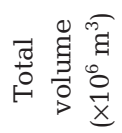 & 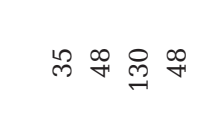 & 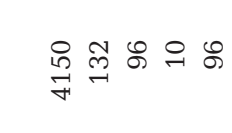 \\
\hline 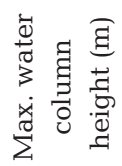 & ஸे m户 & ㄴ $\stackrel{\sim}{\sim} \underset{\sim}{\sim}$ \\
\hline 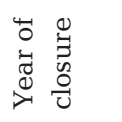 & 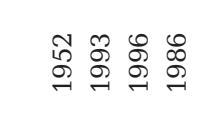 & 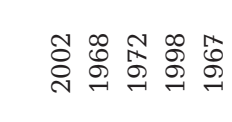 \\
\hline 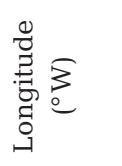 & 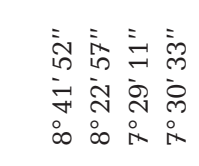 & 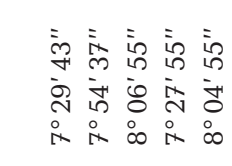 \\
\hline$\underset{\substack{0 \\
\stackrel{0}{0}}}{\substack{0 \\
\bullet}}$ & 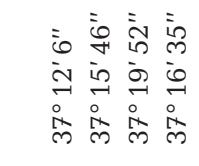 & 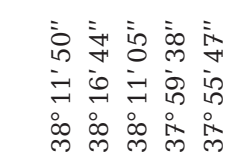 \\
\hline 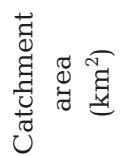 & 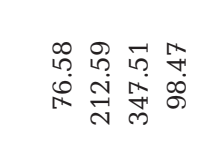 & 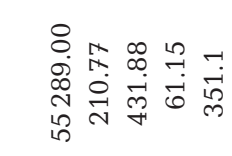 \\
\hline 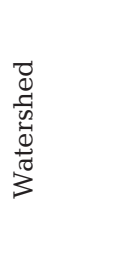 & 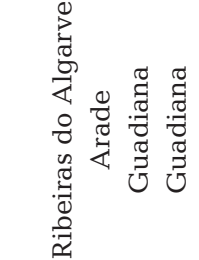 & 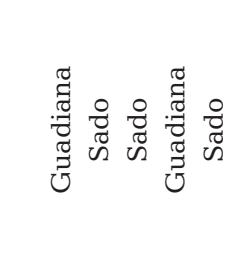 \\
\hline 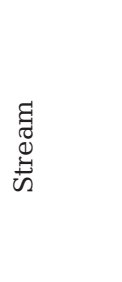 & 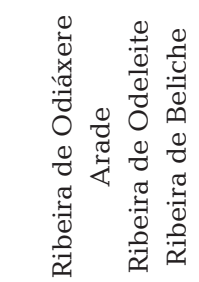 & 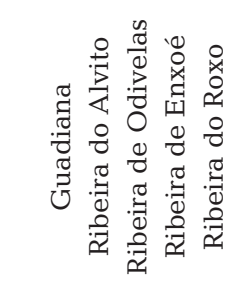 \\
\hline $\begin{array}{l}:= \\
0 \\
0 \\
0 \\
0 \\
01\end{array}$ & 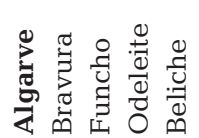 & 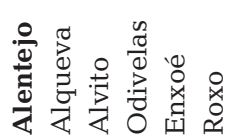 \\
\hline
\end{tabular}




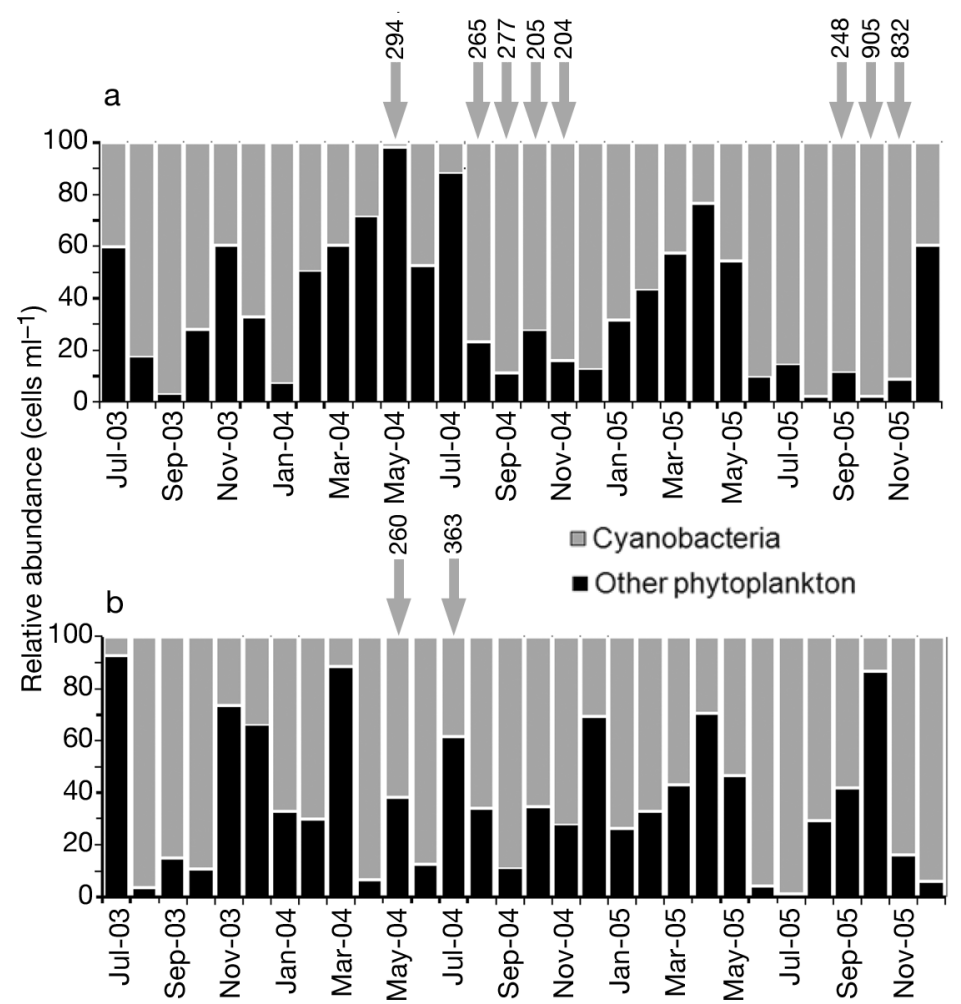

Fig. 5. Relative abundances of cyanobacteria in the Western Algarve reservoirs, (a) Bravura and (b) Funcho. Arrows show samples positive for microcystins; values beside arrows represent microcystin concentrations $\left(\mathrm{ng} \mathrm{l}^{-1}\right)$

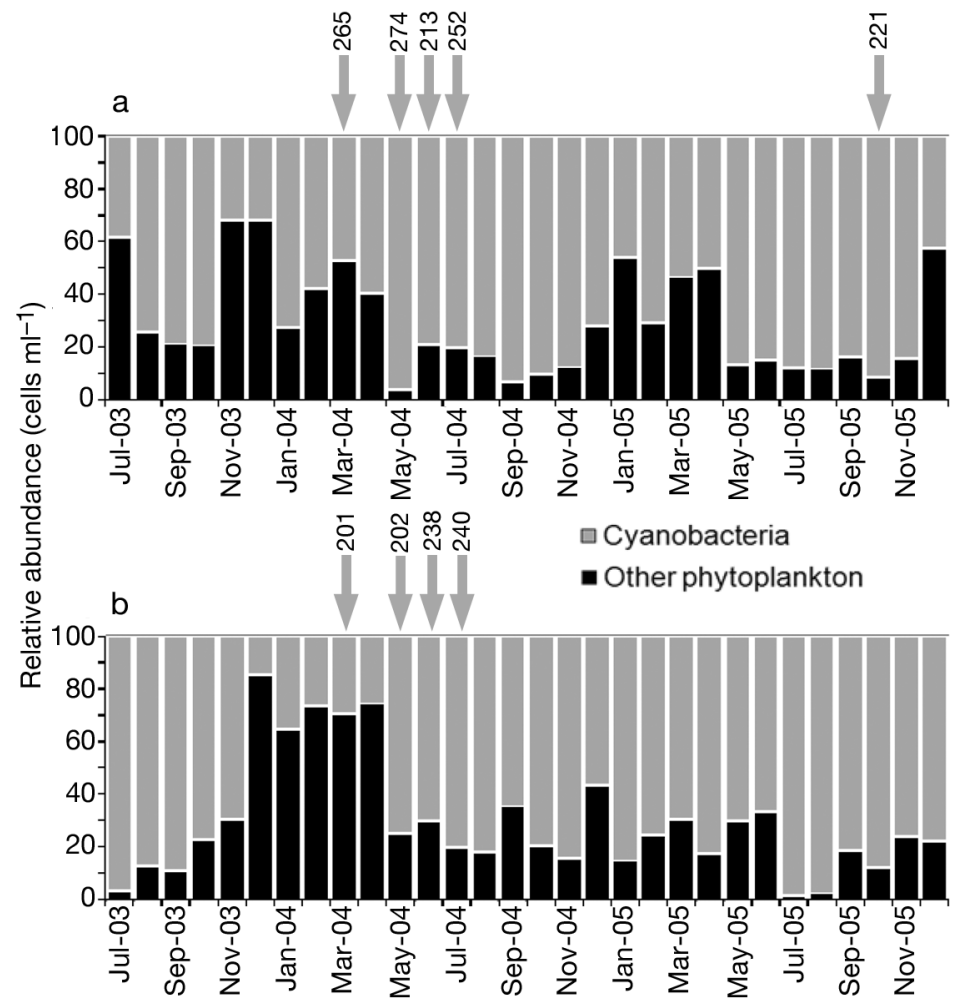

later. This difference could only be explained by the artificial reinforcement of the Funcho thermocline, caused by year-round cold water removal from the hypolimnion for drinking water production.

Concerning the 2 eastern reservoirs, management of the underground channel between Odeleite and Beliche artificially induced a polymictic behavior that can also be associated with conditions favouring blooms of filamentous cyanobacteria through the resuspension of bottom sediment and nutrients. This hydraulic regulation may also have caused differences in the observed phytoplankton succession. The eastern reservoirs (Odeleite and Beliche) systematically developed mixed cyanobacterial blooms of Nostocales and Oscillatoriales in late spring, which were then gradually replaced by Chroococcales. However, in 2005, the channel between Odeleite and Beliche was opened earlier because of a severe drought. Nutrients and akinetes were resuspended in cold waters unfavourable for Nostocales blooms. During this drought, Chroococcales dominated spring blooms even in the eastern reservoirs.

Based on the dominance of cyanobacteria, all 4 reservoirs could be considered eutrophic, but based on soluble reactive phosphorus (SRP) and dissolved inorganic nitrogen (DIN) concentrations, the western reservoirs (Bravura and Funcho) would be classified as slightly mesotrophic and the eastern (Odeleite and Beliche) as oligotrophic. Frequent cyanobacterial blooms occurring in oligotrophic reservoirs are in contradiction with most published reports, which correlate bloom formation with eutrophication or low N:P ratios (Chorus 2001).

Fig. 7 illustrates how blooms and associated DIN:SRP ratios in Funcho were related to the Redfield ratio of $16 \mathrm{~N}: 1 \mathrm{P}$. In fact, DIN never exceeded the desirable limit for a lake in an arid region (US Environmental Protection Agency standard, www.epa.gov/waterscience/criteria/ nutrient) in the eastern reservoirs. In the western reservoirs, this value was only exceeded occasionally in winter. In view of potential SRP-limitation, cyanobacterial blooms during summer were generally not linked to SRP levels, except for the 2002 winter bloom.

Fig. 6. Relative abundances of cyanobacteria in the Eastern Algarve reservoirs (a) Odeleite and (b) Beliche. Arrows show samples positive for microcystins; values beside arrows represent microcystin concentrations $\left(\mathrm{ng} \mathrm{l}^{-1}\right)$ 


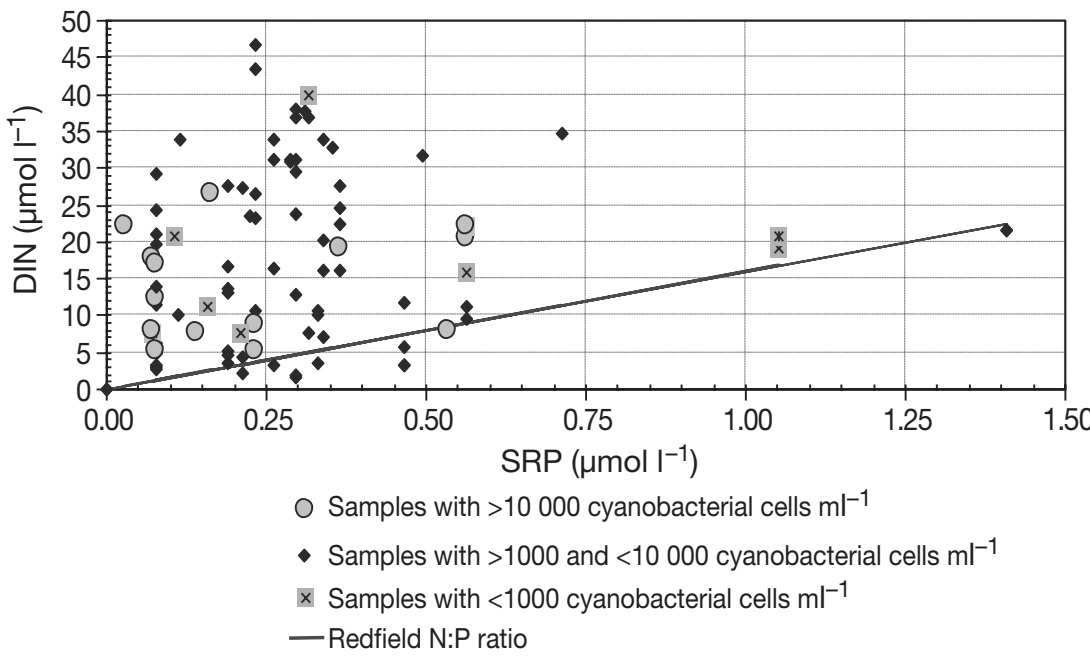

Fig. 7. Relation between cyanobacterial cell concentration and molar proportions of dissolved inorganic nitrogen (DIN) to soluble reactive phosphorus (SRP) in the Funcho reservoir in western Algarve (July 2001 to June 2004). The line indicates the $16 \mathrm{~N}: 1 \mathrm{P}$ Redfield ratio

Exclusive use of physical and chemical data in multivariate analysis of bloom dynamics was not sufficient to discriminate bloom conditions (Reis 2005). This led to the inclusion of biological variables in multivariate analysis of bloom dynamics. Using methods such as distance based redundancy analysis (db-RDA), summer Chroococcales blooms could be associated with increased temperature while the winter Aphanizomenon flosaquae bloom was associated with increased SRP. Trend analysis through dynamic factor analysis (Zuur et al. 2003) applied to biological variables revealed no seasonal pattern and a tendency towards decreasing frequency and density of cyanobacterial blooms. This could be related to the fact that these reservoirs are relatively young water bodies that have not yet developed a stable food web with effective top-down control (Reis 2005).

\section{Cyanobacterial blooms and associated microcystins in freshwater reservoirs in the Alentejo region}

The occurrence of microcystins in Portuguese freshwater resources has been mostly associated with blooms of Microcystis aeruginosa, although other potentially toxic species also occur (Vasconcelos 1993, 1994, 2001, Vasconcelos et al. 1996, Pereira et al. 2001, Vasconcelos \& Pereira 2001, Moreno et al. 2003, Saker et al. 2005). A wide range of microcystin concentrations have been encountered in many Portuguese rivers and reservoirs, though most reports are based on the sporadic analysis of environmental samples taken at the time of a bloom event, rather than on a systematic survey of aquatic ecosystems.
In this study, cyanobacteria and microcystins were monitored in 5 Portuguese freshwater reservoirs over 2 consecutive time periods, from May to December of 2005 and from April to July of 2006. This was intended to evaluate changes in microcystin concentrations and persistence with respect to variations in cyanobacterial assemblages and biomass throughout the sampling period. Table 1 lists some basic information about each of the 5 reservoirs included in the study (Alqueva, Alvito, Enxoé, Odivelas and Roxo), while Fig. 1 shows their location.

Results concerning phytoplankton abun dance and microcystin concentrations found in each reservoir during the monitoring period are shown in Fig. 8. The occurrence of cyanobacteria seemed to follow a seasonal pattern in most reservoirs, with major peaks being detected during summer periods and lower cell densities during cold periods. Although this appeared to be a general trend, the different reservoirs also showed varying patterns in terms of bloom-forming species abundance, biomass and toxicity. In Alqueva, a noticeable shift in phytoplankton composition towards cyanobacterial dominance was observed from July to October 2005. After being replaced by chlorophytes and cryptophytes during spring 2006, cyanobacteria dominated the phytoplankton again in July 2006. Microcystis aeruginosa and Anabaena circinalis were the predominant bloom-forming species, accounting for 11 to $100 \%$ and 3 to $58 \%$ of total cyanobacterial biomass, respectively. However, although both potentially toxic species reached high cell densities, microcystins were not detected throughout the sampling period.

A different pattern was observed in the Alvito reservoir, where microcystins were detected in several samples containing high counts of cyanobacteria. Although different bloom-forming species were found, toxin concentrations were better correlated with $\mathrm{Mi}$ crocystis aeruginosa biomass than with total cyanobacterial biomass. In fact, Anabaena circinalis dominated the cyanobacterial assemblage from July to August 2005, subsequently being replaced as a dominant species by Aphanizomenon flos-aquae, which formed an extremely dense bloom in September. During this period, the relative contribution of $M$. aeruginosa to the overall cyanobacterial community never exceeded $4 \%$ of total cell counts, and microcystins remained below $1.10 \mu \mathrm{g}^{-1}$. However, an increase in toxin concentration in October was associated with a change in bloom 


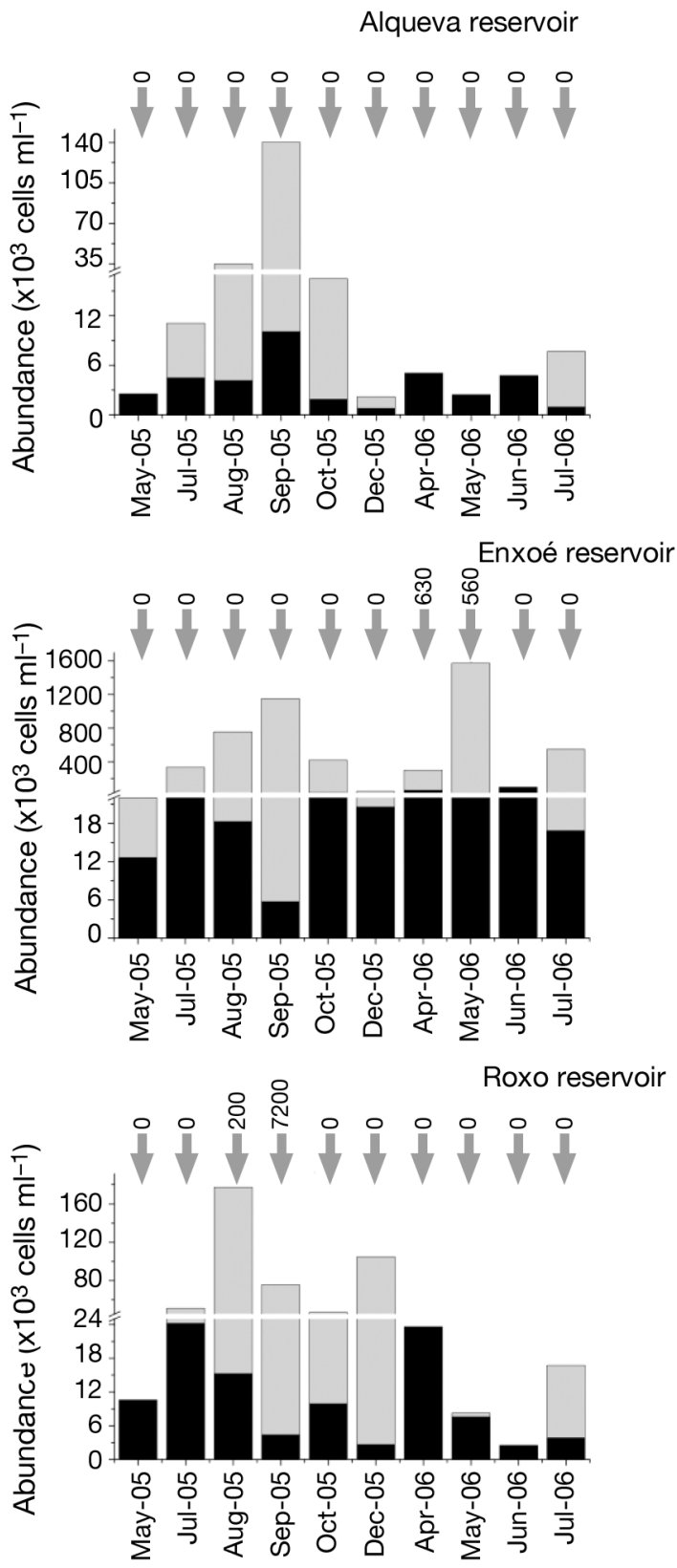

composition, with abundances shifting towards $M$. aeruginosa dominance. Although cyanobacteria were present in much lower total cell counts, microcystins reached a maximum of $2.58 \mu \mathrm{g} \mathrm{l}^{-1}$ during this period.

In Enxoé, 2 phytoplankton blooms were observed throughout the sampling period. The first one occurred in September 2005, following a steady increase in cyanobacterial biomass throughout the summer period. The second bloom occurred in May 2006, when an extremely high abundance of cyanobacteria occurred after a period of low cell counts during winter. Both blooms were dominated by Planktothrix spp. However, microcystins were only detected during the second bloom. Interestingly, no cyanobacteria were
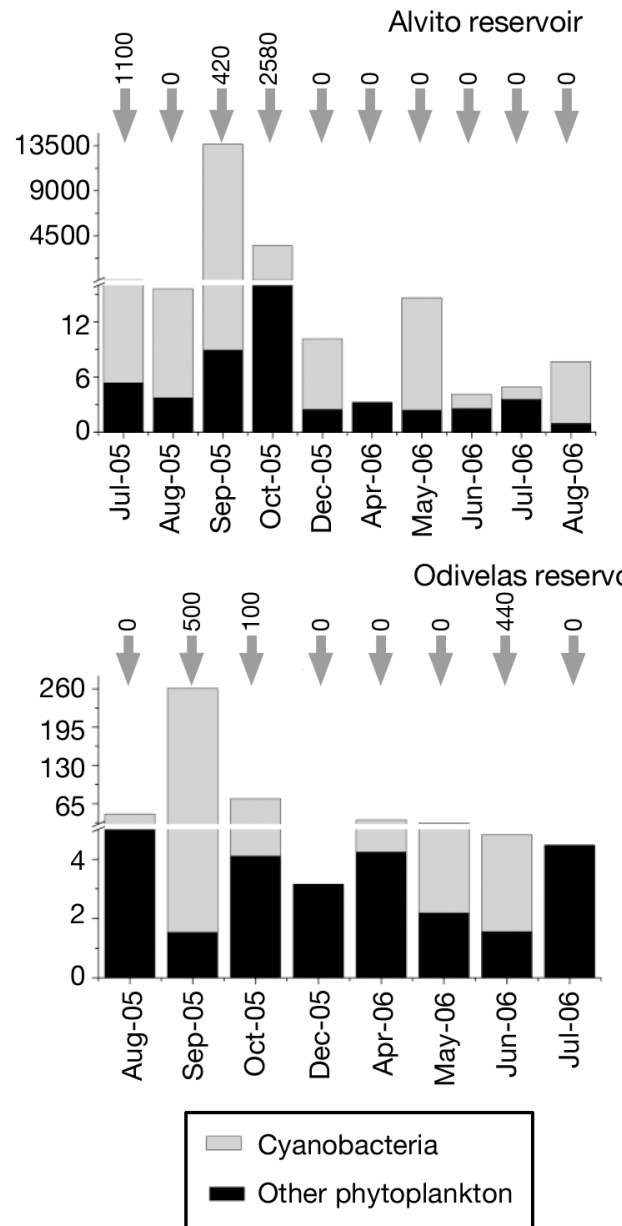

Fig. 8. Phytoplankton abundances and microcystin concentrations in the 5 Alentejo reservoirs. Values above arrows represent microcystin concentrations $\left(\mathrm{ng} \mathrm{l}^{-1}\right)$

found in June 2006, just one month after the major peak in toxic cyanobacteria. Subsequently, Planktothrix spp. dominated again in July and microcystins were below detection limits, similar to the pattern observed in the previous year. In fact, microcystin concentrations did not even co-vary with Planktothrix spp. cell counts during the 2006 toxic bloom, when no other potentially toxic species were found.

In Odivelas, 2 distinct cyanobacterial blooms also occurred, but with a different species composition. In August 2005, 3 different species of Aphanizomenon spp. predominated, contributing ca. $40 \%$ of the total cyanobacterial counts. Other species, such as Anabaena spp. and Microcystis aeruginosa, were also 
detected, but with much lower relative abundances (12 and $14 \%$ of total cyanobacterial counts, respectively). One month later, predominance shifted sharply towards $M$. aeruginosa, with abundances increasing from 6500 cells ml ${ }^{-1}$ in August to 131000 cells ml $^{-1}$ in September, representing ca. $50 \%$ of total cyanobacterial cell counts. Microcystin concentrations detected in the Odivelas reservoir were associated with high $M$. aeruginosa cell counts and reached a maximum of $0.5 \mu \mathrm{g} \mathrm{l}^{-1}$ in September 2005. This $M$. aeruginosa bloom was followed in October by an Aphanizomenon spp. bloom, during which $M$. aeruginosa abundance decreased to $<1300$ cells ml ${ }^{-1}$. Cyanobacteria were not observed during winter, but dominated the phytoplankton in the following spring with a different species composition. In fact, cyanobacterial blooms were mainly composed of Microcystis wesenbergii from April to May 2006, while microcystins were not detected.

In the Roxo reservoir, high cyanobacterial counts occurred from July to December 2005. Two cyanobacteria species dominated successively: Microcystis incerta in July and August (ca. $60 \%$ of the total cyanobacterial cell counts), followed by Planktothrix sp. from September until December. High levels of microcystins were only detected at the onset of the Planktothrix sp. bloom in September 2005. In 2006, cyanobacterial blooms did not occur until July, when Planktothrix sp. reached abundances of 15500 cells $\mathrm{ml}^{-1}$.

\section{DISCUSSION}

The 3 studies presented here used different yet complementary approaches towards understanding the complexity of cyanobacterial bloom dynamics in different ecosystems subject to different sets of varying environmental constraints, which represent a major challenge for implementing adequate water management strategies.

The first study addressed the impact of a recently constructed dam on phytoplankton succession and cyanobacterial blooms in the Guadiana upper estuary and focussed on changes in hydrography and sediment load as well as light and nutrient regime. The second study examined cyanobacterial bloom dynamics in different freshwater reservoirs in the Algarve region in an attempt to discern general patterns in bloom occurrence as well as triggering factors. The third study evaluated seasonal changes in microcystin concentrations in relation to shifts in cyanobacteria species dominance, in terms of abundance and biomasses, in 5 freshwater reservoirs in the Alentejo region. Taken as a whole, these studies emphasize the need for a comprehensive approach towards understanding cyano- bacterial bloom dynamics and toxin production in natural environments in order to correctly assess potential risk and outline adequate monitoring programs.

Initially, the impact of the Alqueva dam on phytoplankton dynamics was predicted to increase the predominance of cyanobacteria with a higher potential toxicity (Rocha et al. 2002). Instead, both cyanobacterial abundance and numbers of toxic species tended to decrease in 2003, after the period of dam construction and filling. Cyanobacterial peak abundances during summer and fall remained well below the maximum cell counts observed prior to dam construction in 1996 and $1997\left(10^{7}\right.$ to $10^{8}$ cells $\left.\mathrm{ml}^{-1}\right)$, probably due to the interaction of several environmental factors such as photolimitation resulting from increased sediment load and haloinhibition due to deeper intrusion of saltwater in the upper estuary.

Data from the Guadiana estuary collected since 1996 revealed that, in the upper estuary, the seasonal succession of phytoplankton populations generally led to a predominance of cyanobacteria in the summer and fall, which could be explained by the nutrient regime (Rocha et al. 2002). Thus, silica depletion caused the demise of diatom blooms followed by increased abundance of chlorophytes in mid-spring. By the end of spring, nitrogen limitation favoured the predominance of small unicellular cyanobacteria from early summer to mid-fall. However, the construction of the Alqueva dam, which further restricted freshwater flow, caused changes in the nutrient regime with increased silica concentrations (Domingues et al. 2007), sediment load and saltwater intrusion in the upper estuary. In fact, estuarine circulation has probably been affected to such a degree that both the maximum turbidity zone and associated chlorophyll maximum no longer constitute well-defined features in the estuary. Unfortunately, slackwater runs (sampling following tidal excursion upstream during the slackwater phase), which enable proper delineation of longitudinal and vertical profiles, have not been regularly performed since 1998 due to lack of funding. However, a more recent project, financed by the Portuguese National Science Foundation (FCT), resumed this sampling program in 2008.

The freshwater reservoir studies demonstrated that different types of cyanobacterial blooms had diverse origins, while no clear seasonal pattern for cyanobacterial abundances was found. In the Algarve reservoirs, multivariate analysis was a useful tool to interpret reservoir dynamics with respect to water quality (Reis 2005). Cyanobacterial dominance in those reservoirs was not always associated with the nutrient regime, but summer blooms were related to high water temperatures. Water management strategies and water removal level affected water column stratifica- 
tion, thus affecting phytoplankton dynamics and cyanobacterial blooms. In the western reservoirs, the enhancement of water column stratification, caused by the removal of cold water from the hypolimnion, led to the export of nutrients and produced a chemostat-like system for the growth of Chroococcales. In fact, the maintainenance of a warm water surface layer positively selected for cyanobacteria and produced prolonged summer blooms. In the eastern reservoirs, mixing of artificial spring water caused by water level management strategies was associated with late spring blooms of Nostocales and Oscillatoriales, probably due to nutrients and akinete resuspension.

Meteorological conditions such as temperature and radiation could not be associated with total cyanobacterial abundances but only with particular bloomforming species. Furthermore, trend analyses revealed that the abundance of bloom species decreased in both oligotrophic and mesotrophic reservoirs, perhaps due to increased top-down control. Finally, SRP limitation did not seem to affect summer blooms of cyanobacteria. Time series analyses (Legendre et al. 1985, Zuur et al. 2003) could be a useful tool for determining selective mechanisms which affect phytoplankton composition and dominance of cyanobacterial species. However, existing time series lack important ecological data such as competition, viral abundance, predation rates and selective predator abundance, which hinders the predictive accuracy of models for phytoplankton dynamics.

Independent of environmental constraints, the Alentejo reservoir study showed that microcystin concentrations in natural waters were not always related to cyanobacterial biomass or even to the abundance of potencially toxic species. Microcystin concentrations found in Alvito and Odivelas, for example, were related to Microcystis aeruginosa cell counts, suggesting that primarily this species was responsible for toxin production in these reservoirs. However, no microcystins were detected in Alqueva, despite the presence of $M$. aeruginosa. In Roxo, microcystins were only detected in high levels during the onset of the Planktothrix sp. bloom in September 2005. However, no microcystins were found in the following months, despite the prevalence of high abundances of Planktothrix sp. In Enxoé, microcystins were only detected in one Planktothrix sp. bloom, yet toxin concentrations did not follow Planktothrix sp. cell counts during the bloom.

Variations in toxin production between and within cyanobacterial species are well known from laboratory studies based on isolated strains (Rapala et al. 1997, Kameyama et al. 2004, Welker et al. 2004, Saker et al. 2005). Furthermore, blooms may be composed of cyanobacterial assemblages producing different toxins at different rates, while the same bloom-forming species can occur as both toxic and non-toxic forms, which are impossible to differentiate based on morphological examination. In fact, all reservoirs included in this study showed very sharp changes in cyanobacterial abundance, whereas marked differences in toxicity were observed both between blooms and within the same bloom. These observations emphasize the irregular pattern of cyanobacterial blooms and cyanotoxin production. Consequently, there is a pressing need for the implementation of systematic monitoring programs of cyanobacteria and cyanotoxins in natural waters in order to minimize potential health risks to animal and human populations resulting from exposure through drinking water and recreational activities.

\section{CONCLUSIONS}

The need for better integration of ecological aspects in water quality assessment is generally accepted, but the European Union Directive (http://ec.europa.eu/ environment/water/water-framework/) that encompasses measures for protection of the ecological quality of waters is far from being fully implemented. Systematic approaches to reservoir ecology should lead to the establishment of ecological water quality criteria, which in turn should help to outline adequate monitoring programs with specific time-scale adjustments, depending on the ecosystem. Ecological water quality criteria should be useful not only in promoting environmental conservation and rehabilitation but also as a tool for raw water management, allowing, for instance, drinking water treatment plants to more efficiently adjust their technologies for the removal of Cyanobacteria and cyanotoxins.

Acknowledgements. The Guadiana estuary monitoring was funded by a series of projects 16/REGII/6/96 and 15/ REGII/6/96 (INTERREGII program), EMERGE (ODIANA regional program), project nr. 45 (Risk evaluation of toxic blooms in lower Guadiana) from LEADER+ program. We also thank A. Matthiensen, C. Rocha, and C. Sobrino for contributing to different parts of this study at different times. R. Domingues acknowledges PhD Grant SFRH/BD/27536/2006 and E. Valério PhD Grant SFRH/BD/8272/2002 from the Portuguese Science and Technology Foundation (FCT). Algarve reservoirs were studied within the framework of 4 research projects, namely CIANOTOX (2001 to 2004), funded by the regional water management company Águas do Algarve, S.A., and CIANOALERTA I, II and III (2003 to 2008) funded through INTERREG IIIA, contracts $\mathrm{n}^{\circ}$ SP5/P35/01, SP5/P19/02 and SP5/P138/03 in collaboration with Águas do Algarve, the regional coordination commission CCDR-Algarve (Portugal), University of Huelva and the Southern Spain water management company GIAHSA (Spain). H.M.G., M.P.R. and P.P. coordinated the composition of the manuscript. H.M.G. coordinated and A.B., S.C., R.B.D., R.M. and M.P.R. participated in 
the Guadiana estuary study. M.P.R. coordinated the research and D.L., S.C., R.M., C.C. and C.G. participated in the Algarve reservoir study. P.P. coordinated and E.V., N.F. and S.P. participated in the Alentejo reservoir study.

\section{LITERATURE CITED}

Berg K, Carmichael WW, Skulberg OM, Benestad C, Underdal B (1987) Investigation of a toxic-water bloom of Microcystis aeruginosa (Cyanophyceae) in Lake Akersvatn, Norway. Hydrobiologia 144:97-103

Berger WH, Parker FL (1970) Diversity of planktonic Foraminifera in deep sea sediments. Science 168:1345-1347

Cabeçadas G, Brogueira MJ (1981) Notas sobre a qualidade da água do Rio Guadiana. Instituto Nacional de Investigação das Pescas e do Mar, Lisboa (in portuguese)

Caetano S, Miguel R, Mendes P, Galvão H, Barbosa A (2001) Cyanobacteria blooms and cyanotoxin occurrence in the Guadiana (SE-Portugal) - Preliminary results. Ecotox Environ Restor 4:53-59

Carmichael WW (1996) Toxic Microcystis and the environment. In: Watanabe MF, Harada KI, Carmichael WW, Fujiki H (eds) Toxic microcystis. CRC Press, Boca Raton, FL, p 1-11

Carmichael WW, Min-Juan Y, Zheng-Rong H, Jia-Wan $\mathrm{H}_{\text {, }}$ Jia-Lu Y (1988) Occurrence of the toxic cyanobacterium (blue-green alga) Microcystis aeruginosa in central China. Arch Hydrobiol 114:21-30

Chorus I (2001) Cyanotoxins: occurrence, causes, consequences. Springer Verlag, Berlin

Chorus I (2005) Current approaches to cyanotoxin risk assessment, risk management and regulations in different countries. Federal Environmental Agency, Dessau-Roßlau

Chorus I, Bartram J (1999) Toxic cyanobacteria in water-a guide to their public health consequences, monitoring and management. E \& FN Spon, London

Cloern JE (1987) Turbidity as a control on phytoplankton biomass and productivity in estuaries. Cont Shelf Res 7: 1367-1381

> Cloern JE (1996) Phytoplankton bloom dynamics in coastal ecosystems: a review with some general lessons from sustained investigation of San Francisco Bay, California. Rev Geophys 34:127-168

> Cloern JE (1999) The relative importance of light and nutrient limitation of phytoplankton growth: a simple index of coastal ecosystem sensitivity to nutrient enrichment. Aquat Ecol 33:3-16

Codd GA (2000) Cyanobacterial toxins, the perception of water quality, and the prioritisation of eutrophication control. Ecol Eng 16:51-60

Codd GA, Morrison LF, Metcalf JS (2005) Cyanobacterial toxins: risk management for health protection. Toxicol Appl Pharmacol 203:264-272

Dittmann E, Wiegand C (2006) Cyanobacterial toxins occurrence, biosynthesis and impact on human affairs. Mol Nutr Food Res 50:7-17

Domingues RB, Galvão H (2007) Phytoplankton and environmental variability in a dam regulated temperate estuary. Hydrobiologia 586:117-134

Domingues RB, Barbosa A, Galvão H (2005) Nutrients, light and phytoplankton succession in a temperate estuary (the Guadiana, south-western Iberia). Estuar Coast Shelf Sci 64:249-260

Domingues RB, Sobrino C, Galvão H (2007) Effects of reservoir filling on phytoplankton succession and cyanobacteria blooms in a temperate estuary. Estuar Coast Shelf Sci
$74: 31-43$

Druvietis I (1997) Observations on cyanobacterial blooms in Latvia's Inland. In: Reguera B, Blanco J, Fernández ML, Wyatt T (eds) Harmful algae. Xunta de Galicia, Intergovernamental Oceanographic Commision of UNESCO, Vigo, p 35-36

Falconer IR (2005) Cyanobacterial toxins of drinking water supplies-cylindrospermopsins and microcystins. CRC Press, Boca Raton, FL

Haas LW (1982) Improved epifluorescence microscopy for observing planktonic microorganisms. Ann Inst Oceanogr 58:261-266

Hutchinson GE (1961) The paradox of the plankton. Am Nat 95:137-145

Hutchinson GE (1967) A treatise on limnology. John Wiley \& Sons, New York

Kameyama K, Sugiura N, Inamori Y, Maekawa T (2004) Characteristics of microcystin production cell cycle of Microcystis viridis. Environ Toxicol 19:20-25

- Kawara O, Yura E, Fujii S, Matsumoto T (1998) A study on the role of hydraulic retention time in eutrophication of the Asahi river dam reservoir. Water Sci Technol 37: 245-252

Kononen K, Kuparinen J, Makela K, Laanemets J, Pavelson J, Nömmann $S$ (1996) Initiation of cyanobacterial blooms in a frontal region at the entrance to the Gulf on Finland, Baltic Sea. Limnol Oceanogr 41:98-112

> Legendre P, Dallot S, Legendre L (1985) Succession of species within a community: chronological clustering, with applications to marine and freshwater zooplankton. Am Nat $125: 257-288$

Magurran A (1988) Ecological diversity and its measurement. Princeton University Press, Princeton, NJ

Moreno I, Cameán A, Tavares MJ, Pereira P, Franca S (2003) Toxicity of cyanobacteria isolated from the Guadiana River. Aquat Ecosyst Health Manag 6:409-413

Oliveira MR (1985) Relatório dos estudos biológicos realizados no Rio Guadiana e na estação. de tratamento de águas da vila de Mértola. Relatório Técnico e Científico do IPIMAR, Lisboa (in portuguese)

Oliveira MR (1991) Eutrofização do Rio Guadiana. Blooms de cyanophyceae e influência na ictiofauna. Relatório Técnico e Científico do INIP, Lisboa (in portuguese)

Pereira P, Onodera H, Andinolo D, Franca S, Araújo F, Lagos N, Oshima Y (2001) Co-occurrence of PSP toxins and microcystins in Montargil freshwater reservoir, Portugal. In: Hallegraeff GM, Blackburn SI, Bolch CJ, Lewis RJ (eds) Harmful algal blooms 2000. IOC, UNESCO, Paris p 108-111

Pinckney JL, Paerl HW, Harrington MB, Howe KE (1998) Annual cycles of phytoplankton community-structure and bloom dynamics in the Neuse River Estuary, North Carolina. Mar Biol 131:371-381

Rapala J, Sivonen K, Lyra C, Niemelä SI (1997) Variation of microcystins, cyanobacterial hepatotoxins, in Anabaena spp. as a function of growth stimuli. Appl Environ Microbiol 63:2206-2212

Reis MP (2005) Dynamics of cyanobacteria blooms in Funcho reservoir (Algarve-Portugal) - a multivariate analysis. $\mathrm{PhD}$ Thesis, Universidade do Algarve, Faro, Portugal

Rocha C, Galvão H, Barbosa A (2002) Role of transient silicon limitation in the development of cyanobacteria blooms in the Guadiana estuary, south-western Iberia. Mar Ecol Prog Ser 228:35-45

> Saker ML, Fastner J, Dittmann E, Christiansen G, Vasconcelos VM (2005) Variation between strains of the cyanobacterium Microcystis aeruginosa isolated from a Portuguese river. J Appl Microbiol 99:749-757 
Sivonen K, Jones GJ (1999) Cyanobacterial toxins. In: Chorus I, Bartram J (eds) Toxic cyanobacteria in water. A guide to their public health consequences, monitoring and management. WHO. E \& FN Spon, London, p 41-111

Smetacek V (1985) The annual cycle of Kiel Bight plankton: a long term analysis. Estuaries 8:145-157

Sobrino C, Matthiensen A, Vidal S, Galvão H (2004) Occurrence of microcystins along the Guadiana estuary. Limnetica 23:133-143

Vasconcelos VM (1993) Toxicity of cyanobacteria in lakes of North and Central Portugal. Ecological implications. Verh Internat Verein Limnol 25: 694-697

Vasconcelos VM (1994) Toxic cyanobacteria (blue-green algae) in Portuguese fresh waters. Arch Hydrobiol 130: 439-451

Vasconcelos VM (2001) Freshwater cyanobacteria and their toxins in Portugal. In: Chorus I (ed) Cyanotoxins: occurrence, causes, consequences. Springer Verlag, Heidelberg p 62-67

Submitted: M;arch 3, 2008; Accepted: August 5, 2008
Vasconcelos VM, Pereira E (2001) Cyanobacteria diversity and toxicity in a wastewater treatment plant (Portugal). Water Res 35:1354-1357

> Vasconcelos VM, Sivonen K, Evans WR, Carmichael WW, Namikoshi M (1996) Hepatotoxic microcystin diversity in cyanobacterial blooms collected in Portuguese freshwaters. Water Res 30:2377-2384

Welker M, Brunke M, Preussel K, Lippert I, von Döhren H (2004) Diversity and distribution of Microcystis (Cyanobacteria) oligopeptide chemotypes from natural communities studied by single-colony mass spectrometry. Microbiology 150:1785-1796

WHO (World Health Organization) (1998) Cyanobacterial toxins: Microcystin-LR. In: Guidelines for drinking-water quality. World Health Organization, Geneva, p 95-110

Zuur AF, Fryer RJ, Jollife IT, Dekkere R, Beukema JJ (2003) Estimating common trends in multivariate time series using dynamic factor analysis. Environmetrics 14: $665-685$

Proofs received from author(s): September 14, 2008 